\title{
SUSTAINABLE DEVELOPMENT FOR RECOVERING ECONOMIC CRISIS: A POSSIBLE SOLUTION FOR BRAZIL
}

\author{
AMANDA CAMPELO ${ }^{1} \&$ DIEGO FONTENELE ${ }^{2}$ \\ ${ }^{1}$ Federal University of Piauí, Brazil \\ ${ }^{2}$ Instituto Camilo Filho, Brazil
}

\begin{abstract}
Brazil has been going through a period of intense political turmoil. The impeachment process of former president Dilma Rousseff started in December 2015 and brought significant upheaval to a country that now faces a deep political crisis. Accused of abuse of power, Mrs. Rousseff was charged with criminal administrative misconduct and violation of the federal budget, and in August 2016 was removed from office and replaced by Vice President Michel Temer. The new administration, in conjunction with the National Congress, lost no time in implementing new law reform programs, a questionable tactic designed to dodge lawsuits. To control expenses, Constitutional Amendments such as PEC 241 propose the freezing of public expenditures in health care and education for the next 20 years, potentially harming the development of the country and well-being of the citizens. It is precisely at this moment that Brazilian Urban Policies come into context and one must ask if the current policies are designed to benefit the government and its leaders or the people of Brazil. From this point of view, this paper aims to discuss how public policies that once generated social and economic development have been affected by the presidential impeachment process and how this can become a moment of opportunity to pursue a sustainable development capable of reviving Brazil's economy. Through a social, environmental and economic approach, it is possible to develop a resilient economy capable of surviving, adapting and flourishing in the face of turbulent events. Designing cities that meet future needs, while improving human quality of life over time, is a clever way to develop the country, create meaningful jobs, restore the confidence of people in their institutions and assure the existence of natural resources for future generations. This article is intended to examine the current situation of Brazil's urban policies and to propose feasible solutions within the country's current context, which will benefit the entire population and improve overall quality of life.
\end{abstract}

Keywords: sustainable development, resilient economy, urban policies, right to the city, urban acupuncture.

\section{INTRODUCTION}

The following paper aims to discuss ongoing urban policies in Brazil and how the presidential impeachment process affected them. In the midst of the current political crisis, most cities in Brazil underwent severe structural changes, highlighting the brazen political contest that in many cases left the management of the urbe and well-being of the citizens as a secondary priority.

Successful cities rely on active participation of citizens and commitment of the government to build thoughtful and well-designed urban environments. Urban policies have the potential to set in motion improvements in the city that strengthen the local economy, guarantee quality of life for all citizens and ensure the preservation of natural resources. In this process, is important that all agents of the city are able to participate in decisions that have a direct impact on their lives. The triumph of our cities depends on the ability of people to exert their civic rights to achieve a humane urban environment. Our cities are our legacy; therefore, it is imperative to include the social, environmental and cultural responsibilities of our society in the political agenda.

The Brundtland report [1], defines sustainable development as "development that meets the needs of the present without compromising the ability of future generations to meet their 
own needs". That means awareness of resources consumption, waste management, technology and ways of living and building in the present.

"The satisfaction of human needs and aspirations in the major objective of development. A world in which poverty and inequity are endemic will always be prone to ecological and other crises. Sustainable development requires meeting the basic needs of all and extending to all the opportunity to satisfy their aspirations for a better life." [1].

The concept of urbanity [2], has been used to evaluate the quality of the built environment according to its relationship to the people and consideration of how these spaces welcome citizens and adapt to their needs. This index synthetically describes the qualities of urban spaces according to desirable standards and when coupled with social, environmental and economic analysis, provides insight into existing problems of the built environment. This analysis allows identifying policies that generate undesirable outcomes and allows urban planners to learn from past experiences and to prevent future mistakes.

Zoning laws that encourage construction of housing settlements in the outskirts of cities favours urban sprawl and brings serious undesired ripple effects: longer daily commutes; difficulty accessing city centres; increased dependence on automobiles and fossil fuels; higher volume of cars in the streets; accentuated traffic jams; etc. A policy and land use regulation has tremendous impact on how people live and what they have to do every day. On the other hand, if the same resources were allocated to the creation of mixed-use areas in city centres, it would be possible to decrease distance between home and work; provide people with alternative and healthier ways of commuting such as walking or biking; improve the existing infrastructure; preserve and spread knowledge about historic city centres, etc., all of which could significantly improve the quality of life of the citizens. By spending less time in traffic and having more free time for leisure activities people are able to include healthier habits into their daily routine. What is observed in recent Brazilian policies is an antithetical version to the urban sustainable development guidelines so widely debated in the world right now.

But Brazil does have its own example of successful sustainable urban developments. The city of Curitiba, under the administration of the Mayor and architect Jaime Lerner, underwent an intense process of restructuration, where social interactions were the framework for creating a more vivid and vivacious spaces. His idea is that small scale interventions are capable of transforming a much larger urban context if pinpointed in strategic areas of higher stress, a technique known as urban acupuncture. A localised and community approach that offers feasible solutions for less cost that can quickly be accomplished and will release energy and create positive ripple effects throughout the city as a whole.

\section{REFLECTION OF CURRENT URBAN POLICIES AND THE RIGHT TO THE CITY}

We live in a time where the ideals of human rights have come to the fore with a lot of good intentions to build a better place. Many countries around the world have raised their voice against abuse of power and political corruption as in Russia and South Korea [3]. It was no different in Brazil. When people were exhausted by lies and new corruption scandals every day on the news; they reacted. There were many public manifestations of a pro-impeachment sentiment that demonstrated a collective desire for political change.

According to Harvey [4], these public manifestations mean that people are exercising their collective rights in the process of urbanization:

"The right to the city is therefore much more than a right of individual or group access to the resources that the city incorporates: it is a right to change and reinvent the city according to our deepest desires." 
In the midst of the crisis, the current Mayor of São Paulo, João Doria, was elected and took office January 2017. In the first few weeks of his term, his administration judged it necessary to cover kilometres of graffiti art walls throughout the city with grey spray paint. The measure created much discussion among citizens about an authoritarian act by the government to erase public statements. Artists defended graffiti as an expression of the city they want: "The graffiti is the most present expression of the city; it is the peripheral subject screaming in colors." [5]. Aside from covering artist statements and public manifestos, the urgency of the matter is questionable, given Sao Paulo faces great challenges such as rising unemployment and low levels of public security in the midst of one of the country's deepest recessions.

The acts of the new government of Sao Paulo shows an attempt to silence the voice of artists and public manifestos in the streets instead of working towards constructive dialogue that will have the power to change the reality of the citizens. In addition, it is an authoritarian act that discourages the expression of people and is contrary to the inclusive, participatory and multidisciplinary approach public administration should aspire to.

São Paulo is the biggest city in Brazil, exerting national and international influence in terms of culture, economic and political views. Unfortunately, today it is our greatest example of a city in political and urban crisis. In the last few years São Paulo reacted against paradigms imposed by conservative governments in an attempt to reduce and change habits rooted in traditionalism. Its former mayor, Fernando Haddad, who was in office from 2013-2016, tackled some of these urban issues by attempting to create more public recreational areas, the use of parklets, incentives for food trucks and an overall improvement of urban spaces. But mainly his politics related to urban mobility were the subjects of great polemic during his mandate, with a strong attempt to prioritize pedestrians, bicycles and public transportation over use of private cars. The creation of dedicated cycle routes, cycle paths and bus corridors aimed to reduce the average time spent in transportation and improve the quality of the air and life of the citizens. His administration also approved creation of more than 150-night line buses, modernization of the fleet, buses with GPS, Wi-Fi and created free pass for students from public schools and the unemployed.

Haddad's administration fulfilled goals by re-qualifying public spaces for the overall benefit of the population and prioritizing collective and non-motorized ways of transportation; breaking down existing schemes like the ISS, which is tax on services of any nature; reorganizing and creating new secretariats such as Human Rights, Politics for Women, and Racial Equality, etc. in an attempt to achieve a more participative and democratic city for all citizens. He also created the office of the municipality's general controller to combat corruption and licensed secretariats to regulate real estate approvals, managing to recover more than $\mathrm{R} \$ 600$ million reais ( $\$ 230$ million dollars) of public money. [6].

In terms of mobility, he reinvented the policy of traffic regulation and speed enforcement with radar, reducing speed limits from $90 \mathrm{~km} / \mathrm{h}$ to $70 \mathrm{~km} / \mathrm{h}$ on highways as a measure to protect pedestrians and reduce accidents. São Paulo went from the 7th position to the 58 ${ }^{\text {th }}$ [7], in the world congestion ranking. Even though his measures brought great advancements and a new way of thinking in the city, his politics were strongly criticized by an elite that disliked this social and environmental approach. With acceleration of the political crisis at a federal level towards the end of his term, Haddad's affiliated Worker's Party lost great prestige due to scandals of corruption and the start of the impeachment process. In October 2016, he lost reelection to his successor Joao Doria.

The current administration of Sao Paulo doesn't have the same social approach as its predecessor. Joao Doria graduated in Marketing and is the ex-president of Doria Group. One 
promise of his campaign was to increase the speed limit on highways in the first week of his mandate. He denied that the speed limit reduction had relation to accidents and deaths on the roads. He also wanted to eliminate secretaries of Human Rights and Policies for Women. Extinguishing internationally recognized programs for drug control that tackle crack dependants is also in the agenda [8]. This specific program has helped more than 800 people and improved the area known as "Cracolândia" [9], that were in the past controlled by drug dealers, street dwellers and organized crime.

The media characterizes him as a disciplinarian leader who is using his background as a businessman for the service of people but he seems to have a problem with protesters, artists and activists on the left.

It is noticeable that the current management of Sao Paulo uses marketing and the media to promote public urban policies of immediate reach, skipping the necessary planning and analysis of the overall context so necessary for complex urban studies in a megacity like Sao Paulo. The result is the formulation of weak plans and strategies that do not necessarily have a long-term reach or benefit the greater part of population. This mentality is problematic for the overall development of the city and results in potentially undesirable projects at the expense of public resources that once again fail to improve the well-being of population.

In Brazil, thousands of municipalities and states are having their public policies put at risk due to the excesses of national politics. Many in the country are currently protesting the public spending limiting amendment, called PEC 241. This Constitutional Amendment limits spending on health, education and social assistance by freezing public expenditure to the limit of last year's inflation rate, with the goal to reduce the country's debt. The argument against PEC 241 is that limiting spending also limits investment potential, harming the development of needed programs that could be the catalyst for economic revival. This amendment, which can be extended for up to 20 years, can have devastating consequences by blocking the development of the country and making it harder for Brazil to leave the current state of recession.

In this sense, it is important to understand the need for investments in the cities as a way to generate jobs and revitalize the economy. Public policies with the goal of improving urban environments under the light of sustainability, besides improving overall quality of life for the citizens, have the potential to spark relevant changes in ways of production, consumption and income distribution. In addition, such policies offer tools for Brazilian cities to develop economically. Programs such as "Sustainable Cities" [10], offers agendas for cities to grow sustainability, addressing different segments of public management, data collection and national and international benchmarks, stimulating citizens' development, government and business organizations.

Sustainable design should be part of the planning of any city and any public policy, and not just occasional thinking. In 2013, the federal government prepared projects for the joint initiative of four ministries: Planning, Environment, Mines and Energy and Social Development and Combating Hunger, with the primary objective of encouraging federal institutions to adopt actions aimed at the rational use of natural resources. Consequently, this planning eliminates wasteful public expenditure and stimulates innovation and improves process management. More important than the implementation of the program, is the introduction of strategic planning for institutions that aim for short, medium and long-term results.

\section{URBAN ACUNPUNTURE}

Every city is a complex living organism with overlaying flows of energy that determine how citizens must act [11]. These multiple strings of energy naturally create points of higher 
stress, and Urban Acupuncture works by focusing on strategically pinpointed small-scale interventions that alleviate pressure around entire areas, restoring vital signs and creating positive ripple effects. Many architects believe in this theory, and Jaime Lerner, Brazilian architect and former mayor of Curitiba for three terms, was one of its great defenders.

According to Lerner, what bring life to a city are its people, and the better the quality of life of the city the better it will be for all citizens. He believes that a city is a collective dream, and that the involvements of its inhabitants is essential to build this dream.

"It is crucial to project successful scenarios that can be desired by the majority of population, to the point that they commit to it. Building this vision of the future is a process that acknowledges, welcomes and embraces the multiple visions that managers and inhabitants, planners, politicians, business, and civil society have of their city and set up coresponsibility equations to make it happen." [12].

Urban acupuncture is based on strategic punctual interventions, which are identified through a holistic analysis of the social, economic and environmental aspects of the city and a dialogue between planners and the community. They are aimed at creating new energy and help the desired scenario to be consolidated by triggering positive chain-reactions and helping to cure and enhance the system as a whole.

According to Lerner [13], there are three fundamental issues that bring good quality of urban life:

1. Sustainability: aiming for less consumption of energy, less use of cars, living close to work, using energy efficient materials, etc.

2. Mobility: prioritizing public transportation over private cars; use of all modes available in the most efficient way.

3. Socio-diversity: embracing and celebrating the multiplicity of people that is only possible in urban spaces, ensuring social cohesion and urban safety while allowing for a greater number of encounters within the city and keeping it alive.

These three key points help identifying the issues that are harming the well-being of the population and how urban acupuncture can be used as a technique and design tool for achieving a sustainable urban development that focuses on the needs of people. The idea targets the use of local resources and promotes the idea of citizens caring for the urban renovations, helping boost community morale and catalysing further revitalization. It provides a more realistic and less costly method for city planners to make improvements in communities and counts on participatory planning for achieving greater success.

A small, subtle, bottom-up approach directs a communities' energy in positive ways to heal urban issues and improve the city space. As opposed to large, top-down, mega-interventions that require greater amount of resources, it reclaims the ownership of land for the public and emphasizes the importance of community development through small interventions throughout the city.

\section{CONCLUSION}

Brazil is going through challenging times, but no difficulty is too great to be overcome. Any city, willingly, has the potential to be transformed for better provided it is embraced with a generous and loving approach. It is necessary to look inward at its own culture, and find what is special and unique, then take these characteristics and develop them further.

History shows that times of crises have been successfully surmounted with investments in infrastructure that boosted the confidence of the people, generated jobs and turned the wheel of the economy. Brazil has an abundance of natural resources envied by many 
countries in the world and to protect this wealth is the country's responsibility. The cities have a great amount to do with that.

The changes start locally. But first, it is necessary to spread the knowledge regarding sustainability. Many professionals that work in local governments are still unware of how to achieve a sustainable urban development. Inform professionals and the community about the benefits of sustainable environments means calling people to action. If more people share the same goal and a collective dream is created, better the chances of the success of this project.

The country could greatly benefit from a program at the federal level that goes into cities with intention to dialogue with the local governments. It should be comprised of a skilful group to pass along the knowledge of sustainability and, in dialogue with local multidisciplinary teams, identify the points of higher stress and act as policy advisors. In the next step, the federal government could finance such developments, making sure that were aligned with guidelines of sustainability and complied with desired outcomes that could be pre-defined by a national agenda. This could significantly impact the development of the country as a whole if there were a serious commitment to strategize and put the plan to action. It would build a stronger and wider network to support local governments with knowledge, advisory and financial resources.

Investments in sustainable urban development can turn the wheel of economy by requalifying spaces, creating jobs, boosting the confidence of the people in their institutions, and improving quality of space for all. That means a holistic approach that considers social, economic and environmental aspects and ensures a paced development to a resilient economy. Local, strategic, pinpricks interventions strengthen communities for lesser cost and positive outcomes create ripple effects. Communities grow stronger and the country benefits as a whole.

Brazil has the potential to be a role model for sustainability. The path is neither easy nor fast, but the moment requires attitude and the time to start is now.

\section{REFERENCES}

[1] UN Document: Report of the World Commission on Environment and Development: Our Common Future, http://www.un-documents.net/our-common-future.pdf. Accessed on: 30 Jun. 2017.

[2] Urbanidade e a qualidade da cidade, http://www.vitruvius.com.br/revistas/read/ arquitextos/12.141/4221. Accessed on: 12 Apr. 2017.

[3] Manifestações seguem após impeachment da presidente sul-coreana, http://exame.abril.com.br/mundo/manifestacoes-seguem-apos-impeachment-dapresidente-sul-coreana/. Accessed on: 18 Apr. 2017.

[4] Harvey, D., Rebel cities: from the right to the city to the urban revolution. Verso: London and New York, p. 5, 2013.

[5] Os pixadores de SP acham que estao sendo usados por Doria. https://www.vice.com/ pt_br/article/pixadores-sp-doria. Accessed on: 15 Mar. 2017.

[6] Porque Haddad? Pela continuidade na construção de uma cidade mais humana e democrática, http://cidadesparaquem.org/blog/2016/9/20/por-que-haddad-pelacontinuidade-na-construo-de-uma-cidade-mais-humana-e-democrtica. Accessed on: 12 May 2017.

[7] Sobre a politica habitacional de Haddad e o conluio da midia com o estado. http://cidadesparaquem.org/blog/2017/1/26/sobre-a-poltica-habitacional-de-haddade-o-conluio-da-mdia-com-o-estado. Accessed on: 25 Mar. 2017. 
[8] Entenda o que esta em jogo com a PEC 241. https://www.cartacapital.com.br/politica/ entenda-o-que-esta-em-jogo-com-a-pec-241._Accessed on: 22 Apr. 2017.

[9] Apesar do êxito, programa De Braços Abertos ainda é mal compreendido. http://www.redebrasilatual.com.br/cidadania/2016/09/programa-de-bracos-abertostem-resultados-positivos-e-reconhecimento-internacional-7968.html. Accessed on: 5 Apr. 2017.

[10] Programa Cidades Sustentáveis, http://www.cidadessustentaveis.org.br/. Accessed on: 18 Apr. 2017.

[11] Urban Acunpunture by Jaime Lerner, https://hbr.org/2011/04/urban-acupuncture. Accessed on: 12 Apr. 2017.

[12] Jaime Lerner's Urban Acunpunture. https://dirt.asla.org/2014/09/18/jaime-lernersurban-acupuncture/. Acsessed on: 2 May 2017.

[13] Lerner, J., Urban Acunpunture, Celebrating Pinpricks of Change that Enrich City Life. Island Press, 2014. 